\title{
What Does Mary-Anne Elizabeth Plaatjies-Van Huffel Have to Say to Silent Partners of the Reformed World?
}

\author{
Willie S. Zeze
}

Nkhoma University, Malawi

willy.zeze@gmail.com

\section{Abstract}

This article is a contribution to the Festschrift in honour of the late Mary-Anne Elizabeth Plaatjies-Van Huffel. The author is mindful of the sensitive nature of such writing, especially for her close and extended family members. However, all would agree that though she passed away on 19 May 2020, she still has something to say to women as silent partners. As part of commemorating her life, talents, achievements and contributions, this article specifically addresses the following question: What does Plaatjies-Van Huffel have to say to women who aspire to serve as leaders in the patriarchal Reformed world? I will defend in due course the notion that though she is deceased, she continues to speak. In addressing the question, this article is divided into four parts. The first part recounts her life with a special focus on her education and pastoral academic career. The second part identifies her sources for the practice of church law and church government. The third part comments on her ecclesial political duties in the patriarchal Reformed world, while the fourth part examines her understanding of the hermeneutical causes of challenges facing Christian women, particularly in their attempt to respond to their calling to lead the liberated and unliberated churches and society. The concluding part draws some of her important messages to women who aspire to serve as leaders in the patriarchal Reformed world, where patriarchy is defined as a social system that promotes hierarchies and awards economic, political, and social power to one group over others.

Keywords: silent partners; ecclesial duties; liberated Reformed churches; unliberated Reformed churches; Reformed world; Plaatjies-Van Huffel

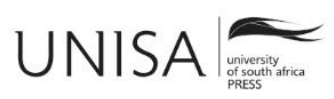


Aim, Method, Sources, and Delimitations

This article is not a comprehensive history of Mary-Anne Elizabeth Plaatjies-Van Huffel's life. Rather, it seeks to discern and convey her message to silent partners, ${ }^{1}$ particularly those who feel called to lead the unliberated Reformed ${ }^{2}$ church and society. In order to do this, the article utilises her personal posts on her Facebook page, published articles as primary sources and research work as secondary sources. In recognition of her many remarkable talents, achievements and contributions, but above all, her indomitable courage manifesting as her timeless message, the following question guides the discussion: What does Plaatjies-Van Huffel have to say to women who aspire to take up leadership positions in the liberated and unliberated Reformed world?

\section{Introduction: Plaatjies-Van Huffel's Life and Times: December 15, 1959-May 19, 2020}

Prof. Mary-Anne Plaatjies-Van Huffel was a remarkable woman. She was the first woman to be ordained as a minister in the then Dutch Reformed Mission Church. The first woman to be elected as Moderator of the Uniting Reformed Church in Southern Africa and the first woman who served as Actuarius of URCSA Cape Synod. She was the first black woman to be promoted to full professor at the Faculty of Theology at Stellenbosch University. She was the World Council Churches president for Africa since 2013. (https://www.remembr.com/en/revprof.mary-anne.plaatjiesvanhuffel)

We begin our discussion with a brief introduction to Plaatjies-Van Huffel, the second of seven daughters of Mr Johannes Jacobus Plaatjies and Mrs Jacoba Johanna Plaatjies. Born in the Northern Cape on December 15, 1959, she matriculated in 1977 at Bergrivier Senior Secondary school in Wellington, Western Cape. After completing her diploma in teaching at the University of the Western Cape in 1978, she embarked on a teaching career for many years until 1986, when she heard God's call to the ministry. She married Rev. Dawid Van Huffel, a full-time minister of URCSA ${ }^{3}$ who by then was serving in Scottsdene Congregation in Kraaifontein, Cape Town.

In responding to God's call, Plaatjies-Van Huffel enrolled at the Faculty of Theology of the University of the Western Cape in order to be trained as a church minister in URCSA. After graduating with a Bachelor of Theology Honours, she became the second woman to be licensed by the curatorium of URCSA (MacMaster 2020, June 1). She was called by Robertson-Robertson East combination congregation and was ordained on 26 November 1992, so becoming the first woman minister of the Word in

1 Silent partners in this article refers to Christian women in general.

2 The liberated Reformed Church, the opposite is the unliberated Reformed churches refers to churches that ordain women.

3 On 14 April 1994, the Uniting Reformed Church in Southern Africa (URCSA) was established through the union of the former Dutch Reformed Mission Church (DRMC) and the Dutch Reformed Church in Africa (DRCA). 
URCSA. Writing on her Facebook page, she recalled her ordination event as well as her most memorable ordeal in the ministry:

I was ordained on 26 November 1992 in Robertson, ten years after the Dutch Reformed Mission Church (DRMC) decided to open the ordained positions for women. As the first ordained women I struggled against subjection, against forms of subjectivity and submission. It was a lonely road. (Plaatjies-Van Huffel Facebook 2019, November 1)

In his congratulatory message on behalf of the Netherlands Missionary Council, Rev. D. Spee was quoted as saying:

The Netherlands Missionary Council wishes to congratulate you with the ordination. We hope that the ordination of Rev. Plaatjies is a start for more congregations to call women as ministers. Our second joy is that it is especially Mary-Anne who is then first female minister at the end of the Lesotho meeting. She gave an outstanding example of her professional theological knowledge and of her ability for pastoral sympathy with a sermon about Ruth. Be convinced that we are happy about this event as much as you are. (Spee, cited in Flaendorp 2014, 55)

Jane Dempsey Douglass, the President of the World Alliance of Reformed Churches (WARC), was quoted writing:

We want you to know how important it is to all of the churches of the World Alliance of Churches, that your church has now opened its ministry to women. We realise that it is not easy for you as the first ordained woman pastor, but it is an exciting opportunity to which the holy Spirit has led you. We know that God will continue to strengthen you for the tasks which lie ahead. (Douglass, cited in Flaendorp 2014, 55)

From these remarks, the following points can be noted. First, even international Reformed bodies realised that it was difficult for Plaatjies-Van Huffel to be a leader in the patriarchal church and society. Second, her church (URCSA) took 10 solid years to materialise its own resolution to ordain women. Third, though no reason is provided as regards why her church delayed in appointing women to the position of leadership, obviously the church was not ready for women ordination. No wonder, as will be explained elsewhere, she described her struggle against all forms of subjectivity as "... a lonely road." On Facebook, she narrated her ordeal in pastoral ministry as follows:

At the beginning of my ministry, one of the congregants refused to allow me to baptize his child. During the administration of the baptism rite, he marched out of the church building with his child in his arms, while shouting aloud: "You are not male, dominee? Christ is male. I will not allow you to baptize my child." (Plaatjies-Van Huffel Facebook 2019, November 1)

She went on to explain her experience: 
Standing there with my hand in the baptismal font, the realisation struck me that the church had failed to deconstruct the theological anthropology which silenced women for centuries. I, therefore, embarked on research for my first $\mathrm{PhD}$, namely about women in the theological anthropology of the Dutch Reformed Mission Church [Vroue in die teologiese antropologie binne die Afrikaanse Gereformeerde Tradisie]. This was a poststructural study. After completion of this $\mathrm{PhD}$ in 2004, the awareness hit me that I was a desolate voice in the desert. (Plaatjies-Van Huffel Facebook 2019, November 1)

These remarks serve as evidence that she encountered serious opposition, even from her fellow Christian women and struggled against various forms of subjections in the church that resolved to ordain silent partners as ministers of the Word. Given the fact that URCSA claims to be one of the Reformed churches that believe in a bottom-to-top system of decision-making, one could doubt if the members of her local church were consulted before or after making the resolution to ordain women to the office of minister. The description of her situation as "a travel alone" and "a voice in the desert" places us at the heart of this article, namely that she has a message to say to women who aspire to serve as leaders in the patriarchal Reformed world.

In acknowledging the emotional and spiritual support she received from her lovely husband, Rev. Dawid van Huffel, a few congregants, members of the church council of Robertson-East congregation, and leaders of the Presbytery of Zuurbraak, she also wrote on her Facebook page:

For 17 years I served in URCSA Roberson-East, a congregation approximately 150 kilometres away from where my husband, Reverend Dawid Johannes Van Huffel, was ministering in URCSA Scottsdene in Kraaifontein. I had to balance my marriage, my role as minister's wife and the daunting task of being a pioneer. (Plaatjies-Van Huffel Facebook 2019, November 1)

In an article "The Relevance of Reformed Church Polity Principles," (Plaatjies-Van Huffel 2014, 41), she remembered that the Church Order of URCSA stipulates that if a church member feels that he or she is wronged or an injustice has been done, or done against the Word of God or the URCSA Church Order, he or she has a right to launch an appeal to the major assembly of the church. However, it is not known whether she adhered to the stipulation.

Narrating another ordeal and experience in her career as a minister of the gospel at a local church, she wrote:

During 1993-1994, 10 months after my ordination, a schism occurred because 120 congregants, mostly women, refused to accept the leadership of a women minister and opted to take up membership in a male colleague's congregation in another part of the town. This schism was reported on extensively in the Afrikaans newspaper, Die Burger, on 23 April 1994. (Plaatjies-Van Huffel Facebook 2019, November 1) 
Though the schism might have had a negative financial impact on an impoverished congregation whose membership comprised primarily of farmworkers, domestic workers, factory workers, and seasonal workers, Plaatjies-Van Huffel remained focused and continued her struggle against gender inequality in the liberated and unliberated Reformed Church. Surprisingly, she never found enough emotional and spiritual support from her female church members.

In 2003, she obtained a first doctorate degree in theology from the University of South Africa (UNISA) on the topic, "Women in the Theological Anthropology in the Afrikaans Reformed Churches" and a post-doctoral degree from the University of Pretoria in 2008. With these qualifications, she courageously continued her work as a pastor and a leader of the patriarchal Reformed congregations and denomination. She commented on her Facebook page:

During the past 25 years, I had to correct countless times members of URCSA as well as male colleagues to address me with the same honorific as my male counterparts, namely "Dominee" [Reverend]. For me, addressing me as "Juffrou" was nothing else than an attempt to constitute me in a role ordinarily assigned in the Reformed mission churches to the minister's wife, meaning to play a supporting role in the ministry towards her husband. (Plaatjies-Van Huffel Facebook 2019, November 1)

She continued, recalling:

I refused to embrace the role of submissiveness. My premise is that roles allocated respectively to women and to men in URCSA and in society at large are constituted by language, and that this construction should be deconstructed. (Plaatjies-Van Huffel Facebook 2019, November 1)

Through these remarks we know who Plaatjies-Van Huffel was and what she stood for and believed in. On the other hand, the same remarks can be considered as part of what she has to say to silent partners, who feel called and are responding to God's call, wherever they may be. Perhaps she is calling them to be courageous and not to accept the ecclesial political duties of submissiveness, but to equally participate alongside male counterparts. In these remarks, she is probably inviting silent partners to forge ahead and listen to the following Scripture:

Therefore, since we are surrounded by so great a cloud of witnesses, let us also lay aside every weight, and sin which clings so closely, and let us run with endurance the race that is set before us, looking to Jesus, the founder and perfecter of our faith, who for the joy that was set before him endured the cross, despising the shame, and is seated at the right hand of the throne of God. (Hebrews 12:1-2)

While serving as a co-pastor of a small, poor congregation of Roberson-East, PlaatjiesVan Huffel was appointed part-time lecturer in systematic theology at Huguenot College in Wellington until 2010. Though this happened, her struggle continued until her dreams were materialised. Writing on her Facebook page, she recalled: 
During the course of time, I applied for numerous synodical positions in the Regional Synod Cape or positions in vacant congregations as minister of the Word in the Cape Peninsula, but even as a holder of two doctorates, recognition of the Western Cape Province for my involvement in the social empowerment of the community of Robertson, I was never appointed in any of these. (Plaatjies-Van Huffel Facebook 2019, November 1)

She went on:

I applied with no avail to four different universities in South Africa for academic positions. Despondent in the church at large, I devoted myself to my ministry and in the executive positions on both the Regional Synod Cape and the General Synod, respectively, as church law expert, assessor, and moderator. (Plaatjies-Van Huffel Facebook 2019, November 1)

Having reached her destination, she looked up to God:

At last, by what I see as God's graceful intervention, I was appointed in 2010 at the University of Stellenbosch as a senior lecturer in ecclesiology and church polity. Since 2008 I have published 17 articles in accredited theological journals, 15 chapters in academic books and I have edited three books. I published primarily in church law, ecumenical church law, law, and religion. I have thrived in this environment, where everyone was subscribing to the ethos of the university regarding equity and equality, and where I was receiving local and global recognition for my scholarly outputs. (Plaatjies-Van Huffel Facebook 2019, November 1)

Like Apostle Paul, who when encouraging Timothy, once said: "I have fought a good fight and have finished the race" (2 Timothy 4:7), Plaatjies-Van Huffel, though she is deceased, still has something to say to female pioneer leaders of the church, academia and society. Her life reveals that "life is a struggle and that living an overcoming life is not something that comes automatically."

In conjunction with the Faculty of Theology at the University of Stellenbosch, in 2012, the Dutch Reformed Church (DRC) and URCSA initiated a new model for spiritual formation and Plaatjies-Van Huffel was assigned to design a programme for theological and spiritual formation for ministerial students. Until this day, this programme, having been approved by the General Synod of URCSA and the DRC in 2012, is in full operation (c.f. Flaendorp 2014, 60).

In the course of her service as an academic professor, Plaatjies-Van Huffel was elected as actuarius (church law expert) of the Cape Regional Synod and as the vice-moderator of the General Synod of URCSA. In most of her research work, she extensively wrote on contextual issues - particularly the question of whether churches should ordain homosexuals and lesbians to the office of ministers of the Word. 
Let me conclude this section by asserting that in many issues, ranging from gender, church history, church law and ecology, Plaatjies-Van Huffel's hardworking endurance and courage remain an audible voice to the silent partners, mostly within the patriarchal Reformed churches. Interestingly, her leadership stretched beyond URCSA borders. There was an intersection between her work as a Reformed ecclesiologist, female pastor and ecumenical leader, her position as a church lawyer and a transformative leader, and a mouthpiece of the silent partners in the Reformed world.

\section{On Sources of Constitutional Theology and Church Law Practice}

In this section, attention is given to Plaatjies-Van Huffel's constitutional theology sources. As said earlier, her sources can be discerned through a critical analysis of the church law sources of URCSA and her interaction with the Constitution of the Republic of South Africa (c.f. Pieter Coertzen 2013, 125). According to her:

The legal sources in URCSA consist of the confessional basis and the Church Order. Amendments to the Church Order and the confessional basis of URCSA, which are the Belgic Confession of Faith, the Heidelberg Catechism, the Canons of the Synod of Dort and the Confession of Belhar. (Plaatjies-Van Huffel 2013, 102)

On the question of the authority of Church Order, she observed:

The Church order of URCSA does not address every situation of the church. Nor does it presume to be exhaustive or to cover everything. Ordinarily, however, when something is not mentioned in the Church Order of URCSA the omission is deliberate and intentional. (Plaatjies-Van Huffel 2013, 102)

Taking into account these remarks, two things can be said. First, most obviously, these remarks reveal her expertise and experience in church history and church law and related matters. For instance, her realisation that "when something is not mentioned in the Church Order of URCSA the omission is deliberate and intentional," is indicative that she was a real team leader and a competent church law expert. Second, her assertion that the Act 108 of 1996 of the Constitution of the Republic of South Africa guarantees everyone the right to freedom of association, ironically implies that the Constitution of South Africa is one of the most important secondary sources for practising church law and church government in URCSA and other churches (Plaatjies-Van Huffel 2013, 102).

Commenting on the same, a renowned Dutch Reformed Church historian and church law expert, Pieter Coertzen $(2013,2)$, in his article "Dordt and South Africa: Church and State Relations in the Netherlands and in South Africa," affirmed that the family of Dutch Reformed Churches in South Africa decided to make some South African Charter of Religious Rights and Freedoms as their official documentation through inclusion in the Church Order book of URCSA (Plaatjies-Van Huffel Facebook 2019, November 1). 
Regarding the South African Labour Act as one of the secondary sources for practising church law in URSA, according to Plaatjies-Van Huffel, the Employment Equity Act 1998 contains a number of provisions providing for affirmative action and protection against, amongst other things, unfair discrimination, and sexual harassment (PlaatjiesVan Huffel 2019b, 107). The Act, in her view, provides for the elimination of unfair discrimination by requiring that every employer must take steps to promote equal opportunity in the workplace by eliminating unfair discrimination in any employment policy or practice (Plaatjies-Van Huffel 2019b, 107). She further said:

The General Synod of URCSA 2005 called upon all church members who can be defined according to the Employment Equity Act 1998 as designated employers to take steps to promote equal opportunity in the workplace by eliminating unfair discrimination in any employment policy or practice, to ensure the implementation of employment equity to redress the effects of discrimination in order to achieve a diverse workforce broadly representative of the population. URCSA emphasizes the elimination of unfair discrimination in employment. URCSA urges local congregation as well as church members, who are designated employers, to adhere to this Act. (Plaatjies-Van Huffel 2013,107)

Taking what she said into account, three things can be noted. First, she affirmed that URCSA aligned some articles of URCSA's book of Church Order with the labour law system of the Republic of South Africa government. In doing this, she implicitly acknowledged that the URCSA legal frame sources consist of the Bible as a primary source, while its four confessions of faith, the Church Order, and various Acts of the country's Constitution serve as secondary sources. Second, according to her, URCSA sees herself as part of a society, in which, as an institution among other institutions and social structures such as the state, the school, industry and others, it lives and works (Plaatjies-Van Huffel 2013,107). Third, for her, URCSA probably works with the presumption that it is necessary to abide by the laws of the state (Plaatjies-Van Huffel 2013, 107).

\section{On Church Polity: Christocracy and Synodocracy ${ }^{4}$}

One of the basic questions in her church polity discourse and practice was whether Jesus Christ is really the head of the church. Plaatjies-Van Huffel cherished the viewpoint of a renowned church polity ecclesiologist of the Dutch Reformed Church, Prof Willie Jonker:

It is the basic principle of all true church polity that Jesus Christ is the only Head of the Church and that His direct and actual reign should be acknowledged in the practical polity of the Church. Yet it seems ... Christ as the living Head of His Church rules

4 Christocracy is the researcher's designation for the rule of Christ in the church through governing assemblies (Zeze 2012, 19, 87, 155, 221). 
directly and actually through His Word and Spirit. (Plaatjies-Van Huffel 2019a, November 2)

She argued:

The church may never and nowhere make the impression that the majority rules in the church and that everyone simply must conform to a majority decision if they feel unhappy or not. In the church it is the power of the Word, not the rule of the majority. This is about consensus reached and not majority vote. That is why the church do their utmost not to force members with scriptural objections to cooperate with the implementation of decisions which they feel burdened. (Plaatjies-Van Huffel Facebook 2019, November 1)

On the subject of synodocracy, Plaatjies-Van Huffel observes that URCSA has a Presbyterian-Synodical system of church governance which is anti-hierarchical, antiEpiscopal, anti-independent as well as anti-congregational (Plaatjies-Van Huffel 2014, 103).

URCSA is governed through a series of governing assemblies or church courts, namely General Synod, Regional Synod, Presbytery (Classis) and Church Council. Each assembly exercises, in keeping with its own character and domain, the ecclesiastical authority entrusted to the church by Christ (c.f. URCSA Regional Synod Church Order 2011 art.44). Regarding the role of a pastor, Plaatjies-Van Huffel explained:

The pastor has power to convene the Church Council. The pastor of the congregation shall always be the chairperson of the Church Council except when it may appear advisable that some other minister in the resort of the presbytery should be invited to preside. (Plaatjies-Van Huffel 2013, 104)

Concerning the relationship and authority of each governing assembly, she said:

All ecclesiastical assemblies of URCSA abide by the agreement laid down in the church. The major assemblies of URCSA have the authority to determine matters of controversy ... During the past decades, a deviation.... For example, the major assemblies of URCSA gradually usurped power in order to make decisions on such matters ... even the confessional basis of the church without giving the minor assemblies the opportunity to participate in the decision-making process. (Plaatjies-Van Huffel 2013,106)

Plaatjies-Van Huffel's career as church history and church law professor at the Faculty of Theology of Stellenbosch University; former co-minister in Scottsdene and Kraaifontein; actuarius of the Cape Regional Synod; and vice-moderator of the General Synod of URCSA, assisted her to achieve the following. First, during her term of office as actuarius, she ensured that the Church Order of URCSA is more gender sensitive. Second, she was a strong voice in the church on church matters as well as on social and 
economic issues. Third, her leadership stretched beyond the church borders and she became a respected South African public persona.

It is my conviction that though Plaatjies-Van Huffel is no longer with us, her voice can still be heard, and her message is conveyed to the silent partners. Putting it differently, in biblical terms, though she is deceased, she is still speaking to Reformed women in the Reformed world (c.f. Hebrews 11:4).

\section{On Prophetical and Ecclesial Political Duties}

Over the course of her career, Plaatjies-Van Huffel touched the hearts, hands and heads of many church women, university professors, academics, church leaders and prospective leaders of African society and beyond. In his analysis of Plaatjies-Van Huffel's theological beacon, Flaendorp says:

Her theological framework was founded on three pillars: a theology of dignity especially towards the vulnerable groups; the theological disciplines of church history and church polity; and a theology of ecology and justice. (Flaendorp 2014, 58)

Though it is not the purpose of this article to offer an in-depth explanation of each of the three pillars, suffice it to say that the pillars were interwoven in her theologicalanthropology, church polity discourse and the practice of all her remarkable talents, achievements and contributions. Today they constitute part of what she has to say to women who feel called to serve in the pastoral ministry.

Plaatjies-Van Huffel observed that in URCSA, in the past, there was a deviation from the Reformed Church polity principles: self-government under the sole headship of Christ; the limited autonomy of the local congregation-restricted power; responsibilities of ecclesial assemblies; the necessity and nature of Christian discipline; and the right of appeal and the power of the major assemblies with regard to misconduct (Plaatjies-Van Huffel 2011, 35-43). It may be argued that such a deviation might have resulted in maladministration, impuissance, heresy or schism, as well as gender insensitivity within URCSA.

At the beginning of her ministry, Plaatjies-Van Huffel was not comfortable with the androcentric nature of URCSA's Church Order, to such an extent that she sent a number of overtures in which she requested for the amendment of the Church Order of URCSA. Commenting on one of her overtures, she said:

I, therefore, submitted during 2002 numerous church judicial amendments, which attended to gender inclusivity, for example to write out both pronoun options as "she or he" or "she/he" and "her/his," or "her/him ... I strongly objected to the usage of androcentric language in the official documentation of URCSA. In the end, the Regional Synod Cape 2002 approved all my recommendations. (Plaatjies-Van Huffel Facebook 2019, November 1) 
Though her recommendations were approved, she recalled that some of the delegates proposed that masculine pronouns (he, his, him) should be used as the default in situations where the person or thing to which you are referring could be either male or female and that a disclaimer should be printed in the introduction to explain the usage of the masculine pronouns (Plaatjies-Van Huffel Facebook 2019, November 1). It was in this way that one would speculate that Plaatjies-Van Huffel developed her hermeneutical model, which was gender sensitive in church judicial matters particularly on how existing and prospective women leaders ought to be treated. On the same, she wrote:

During that time, the General Synod embarked on a process to align the Regional Synods' Church Orders of URCSA (2004-2016). I realized with dismay that androcentric language was still prevalent in all the Church Orders of the Regional Synods of URCSA. The alignment process was concluded at the General Synod 2016. From then on it was expected that all Regional Synods of URCSA should utilize. (Plaatjies-Van Huffel Facebook 2019, November 1)

In harmony with these remarks, four points can be highlighted. First, besides her tireless struggle to make the Church Order of URCSA more gender sensitive, Plaatjies-Van Huffel became a strong voice on women leadership-related matters, as well as on social and economic issues. Second, she developed a sound knowledge of church history and church polity for her students and the church in the African continent and beyond. Third, she became a staunch ecclesial activist and unifier of URCSA provincial synods.

Regarding her appointment to the ecclesial political-prophetic office, she narrated:

I was elected at the Regional Synod Cape 2002 as the church law expert (actuarius), the first woman to fill this position on the Executive of a Regional Synod of URCSA. At the Regional Synod Cape 2006, I was re-elected in this position. From 2002 until 2010 it became my task as a church law expert to ensure that inclusive language would be used in the official documentation of the Regional Synod Cape. (Plaatjies-Van Huffel Facebook 2019, November 1)

Her re-election is indicative that Plaatjies-Van Huffel made an indelible mark in her office as actuarius and also in the hearts and minds of male and female colleagues of the church. At the same time, she never forgot her prophetic duties to fellow women in the liberated and unliberated churches as well as against fake pastors and prosperity gospel preachers.

Addressing what she described as the 21 st century false teachers and false prophets, she wrote:

Currently, in South Africa, we are seeing a lot of people willing to pay huge amounts of money to self-made pastors in order to be healed and/or to prosper in all walks of life, for example to have a promotion, job, house, wife, husband, children et cetera. Desperate people are drinking petrol, eating grass, allowing pastors to spray even Doom in their 
faces. Some are even seeing constituting churches as a way to earn a salary. Religion is for sale in South Africa. (Plaatjies-Van Huffel 2019a, November 2)

She added:

We are called to be faithful believers, responsible citizens in God's world and good stewards of God's creation. Let us equip ourselves to be well-informed about the Reformation and become defenders of biblical truth in our communities. May we engage in our ministries, at work or school and in our neighbourhoods with the theme: i) Salvation is not for sale, ii) Human beings are not for sale, iii) Creation is not for sale, and in so doing spark a new reformation of church and society. (Plaatjies-Van Huffel 2019a, November 2)

Plaatjies-Van Huffel had a keen interest in attending local, national, and international conferences in her capacity as professor and woman minister. Regarding the difficulties that her female theological students often had to face at Stellenbosch University, she used to provide them with spiritual and psychological advice. This is evident from her remarks posted on Facebook and from other sources:

The Curatorium of the Western Cape Synod frequently refers female students to her for consultation when they struggle with their calling. She is able to help these students by sharing her experiences as a woman pastor in active ministry with them. (Plaatjies-Van Huffel cited in Flaendorp 2014, 55

Certainly, being the first ordained woman, and as a church leader who struggled against subjection, against forms of subjectivity and submission on a lonely road, she had and still has much to say to her students and colleagues in the academia.

\section{On Hermeneutical Tools for Addressing Ecclesial-Political Challenges Facing Silent Partners}

I claim that URCSA is not a safe space for ordained women. URCSA pays no heed to the personal sacrifices that most of these pioneering women in URCSA have endured in order to retain the status as ordained women. (Plaatjies-Van Huffel Facebook 2019, 4)

In her article, "Patriarchy as Empire: A Theological Reflection," Plaatjies-Van Huffel observed that societal patriarchy has ramifications for ecclesiastical patriarchy, particularly in the Reformed circles (Plaatjies-Van Huffel 2011, 7). She concurred with Reuther $(1983,97)$ that Reformed Churches, like the 16th century Reformers and Reformed Churches worldwide, have not done much to transform the patriarchal anthropology. Also agreeing with Hamilton $(1987,50)$, she noted that the Reformers only redefined patriarchal anthropology to suit their own particular worldview (Plaatjies-Van Huffel 2011, 7).

In an attempt to address this problem in URCSA, Plaatjies-Van Huffel devised what she called an autoethnographical research approach or cultural hermeneutics consisting of 
telling one's own experience as well as reading and understanding the scriptures in an ecclesial setting. Using this method, she wrote:

Being a minister of the Uniting Reformed Church in Southern Africa serving a congregation in Robertson-East, a small, rural town in the Western Cape, I have become involved in issues of gender equality and the empowerment of women in the church ... Although women had access to decision-making structures of URCSA since 1982 the proportion of women in leadership positions is minimal. (Plaatjies-Van Huffel 2019b, 4)

She argued:

Whilst theoretically women currently have access to leadership positions in church and civil society, these new opportunities are accessible to a narrow pool of women who have had access to skills development, education, and training. (Plaatjies-Van Huffel 2019b, 4)

These remarks probably illustrate three important things: Firstly, that seeds of patriarchy were extensively ingrained, not only in the Reformed Churches but also in all the spheres of every society. Secondly, that like many Reformed Churches, URCSA does not comply with its own gender policy and legislation. Thirdly, that there are pockets of liberated and unliberated spheres within the Reformed world.

Plaatjies-Van Huffel $(2019 b, 4)$ suggested developing appropriate responses to the negative experiences of women in which Reformed Churches and societies should learn from the South African post-structuralism. She wrote:

A post-structural approach to hermeneutics should, amongst other things, show that theological notions on anthropology are nothing more than human projections. New and inclusive metaphors for God are needed in a post-structural approach. (Plaatjies-Van Huffel 2011, 7)

She continued:

The complete humanity of all people created in the image of God (imago Dei) must be accentuated in a post-structural approach, away from dualistic thinking and hierarchical notions, towards a congruent model where both the church structures and the dominant discourse are deconstructed. (Plaatjies-Van Huffel 2011, 7)

Backing her model as a point of departure for addressing social realties, she cited Genesis 1:26-27, especially where it asserts that every human person is created in the image and likeness of God and endowed with invariable human dignity. To her, the underlying principle of equality in a post-structural hermeneutical methodology is that women are completely human. She argued: 
A theological understanding of what it is to be human should stand central in poststructural hermeneutics. In post-structural hermeneutics the emphasis falls on recognizing that the Biblical text has a patriarchal content, and that both the authors and the readers are influenced by the patriarchal framework of thinking. (Plaatjies-Van Huffel 2011, 7)

She then outlined three interrelated hermeneutical problems:

The Bible presents God mainly in male terms, for example God as father, king, judge, et cetera. Female images are used only a few times to refer to God. There are fewer women than men in the Bible. Women are presented in the Bible mainly in relation to men, for example Hannah, Ester, Maria, et cetera. (Plaatjies-Van Huffel 2011, 7)

For her, the Bible is not to be regarded as historiography in the true sense of the word (Plaatjies-Van Huffel 2019b, 4). Rather, the semantics of the entire Bible (for example Genesis $2: 4 b-3: 2$ ) must support the view that the problem lies in the depth structures of texts, and not in the interpretation of texts. She did not hesitate to agree with those who observed a discrepancy in feminist exegesis where some texts (for example Ruth) are placed in a patriarchal context and others (for example Gen 2-3) are placed in a feminist context.

It is evident then, that being an academic and church law expert, Plaatjies-Van Huffel was committed to getting the true meaning of biblical texts in addressing social realities that women are facing. To her colleagues in the academia and church law expert field, she proposed that a paradigm shift in the reading process, hermeneutics, and biblical exegesis should occur and that the patriarchal, hierarchical basis of the anthropology of the church and the societal structures should be replaced with an inclusive, holistic, relational, egalitarian, transformative anthropology (Plaatjies-Van Huffel 2011, 10).

\section{Closing Remarks: What does Plaatjies-Van Huffel have to Say to Women Aspiring to Take Leadership Positions?}

Now we return to where the article started. What does Plaatjies-Van Huffel have to say to Christian women leaders, both in the liberated and unliberated Reformed world? The same question brings us to the concluding point of this article. We now re-emphasise her words: First, "Biblical text has a patriarchal content, and that both the authors and the readers are influenced by the patriarchal framework of thinking ... roles allocated respectively to women and to men ... are constituted by language, and that this construction should be deconstructed" (Plaatjies-Van Huffel 2011, 10). Second, "there was and is no programme ... to monitor the challenges and struggles of ordained women ..." Third, "by concentrating only on the issue of access for women to ordained positions and leadership positions, there is the danger that other exclusionary mechanisms of race, culture, power structures which exist between women and men, are not being addressed" (Plaatjies-Van Huffel 2011, 10). Fourth, the "paternalistic, patriarchal anthropological framework of thinking should be replaced with an inclusive 
theological anthropology in which the communality of both sexes is emphasised" (Plaatjies-Van Huffel 2011, 10).

\section{Autobiography}

Born in 1970 in Malawi, Willie Zeze (DTh) is a church minister of the Church of Central Nkhoma Synod, and a lecturer in the Department of Ecclesiology at Nkhoma University in Malawi. He is an alumnus of the University of Stellenbosch. Prof. Dr Mary-Anne Plaatjies-Van Huffel was his internal examiner during the doctoral thesis examination on 8 February 2012.

\section{References}

Coertzen, P. 2013. "Religion in the Public Sphere of a Pluralistic Society: The South African Attempt, a Reformed Perspective." NGTT 54 (3 \& 4) (September, December). "Enactment on Church Judicial and Legal Issues.” NGTT 54 (Supplement 4, 2013): 111-112. https://doi.org/10.5952/54-3-4-401.

Flaendorp, C. 2014. "The Life and Times of Professor Mary-Anne Plaatjies-Van Huffel: A Transformative Church Leader in Sub-Saharan Africa." Studia Historiae Ecclesiasticae 40 (August Supplement): 53-63.

Hamilton, R. 1987. The Liberation of Women. London: George Allen and Unwin.

MacMaster, L. 2020. “Tribute to Professor Rev. Dr Mary-Anne Plaatjies-Van Huffel.” https://www.uwc.ac.za/Announcements/.

Plaatjies-Van Huffel, Mary-Anne E. 2011. "Patriarchy as Empire: A Theological Reflection." Studia Historiae Ecclesiasticae, December Volume XXXVII. Supplement.

Plaatjies-Van Huffel, Mary-Anne E. 2013. "The Search for a Common Understanding with regard to Ecology and Justice in the Uniting Reformed Church in Southern Africa." Studia Historiae Ecclesiasticae 39 (2) (December): 1-17.

Plaatjies-Van Huffel, Mary-Anne E. 2014. "The Relevance of the Reformed Church Polity Principles: Revisiting the Supplementum 4, 2013," 101-113. http://ngtt.journals.ac.za/pub/article/view/294 pdf.

Plaatjies-Van Huffel, Mary-Anne E. 2019a, November 2. "W. Jonker on Majority Rule/Democracy in the Church." In Om die Regering van Christus in Sy Kerk (1965). Accessed July 10, 2020.

Plaatjies-Van Huffel, Mary-Anne E. 2019b. A History of Gender Insensitivity in URCSA. Studia Historiae Ecclesiasticae 45 (3): 1-22. https://dx.doi.org.625. pdf. Accessed July 2014.

Plaatjies-Van Huffel, Mary-Anne E. Facebook 2019, November 1. Accessed July 11, 2020. https://www.facebook.com/maryanneplaatjiesvanhuffel/. 
Remembrance, B. V. (n.d.) "Utrecht, the Netherlands.” Accessed July 14, 2020.h ttps://www.remembr.com/en/revprof.mary-anne.plaatjiesvanhuffel.

Reuther, R. R. 1983. Sexism and God-talk: towards a Feminist Theology. London: SPCK.

Zeze, W. S. 2012. "Christ, the Head of the Church: Authority, Leadership and Organizational Structure of the Church of Central Africa Presbyterian." Unpublished doctoral thesis, University of Stellenbosch. 